phenotypes were associated with specific MSA. After 5 years, 2/3 of patients had an inactive disease, but about half of all patients still received MTX and GC therapy.

Disclosure of Interests: Claudia Sengler: None declared, Svea Horn: None declared, Nadine Grösch: None declared, Jens Klotsche: None declared, Martina Niewerth: None declared, Fabian Speth: None declared, Peter Haas Grant/research support from: Pfizer, Claas Hinze: None declared, Gerd Horneff: None declared, Tilmann Kallinich Grant/research support from: Novartis, Speakers bureau: Sobi, Roche, Novartis, CLB, Frank Weller-Heinemann: None declared, Nadine Unterwalder: None declared, Kirsten Minden Consultant for: AbbVie DOI: 10.1136/annrheumdis-2019-eular.3253

\section{THU0522 \\ CLINICAL MANIFESTATIONS AND COMPARISON OF SUBTYPES OF JUVENILE IDIOPATHIC INFLAMMATORY MYOPATHIES: DATA FROM THE REMICAM REGISTRY}

Jesús Loarce-Martos ${ }^{1}$, Carmen Larena ${ }^{1}$, M. Ángeles Blázquez ${ }^{1}$, Beatriz JovenIbáñez ${ }^{2}$, Patricia Carreira ${ }^{2}$, Francisco J López-Longo ${ }^{3}$, Julia Martinez-Barrio ${ }^{3}$, J. C. López Robledillo ${ }^{4}$, Raquel Almodovar ${ }^{5}$, María Jesús García de Yébenes ${ }^{6}$, Laura Nuño ${ }^{7}$, REMICAM. ${ }^{1}$ HU Ramón y Cajal, Madrid, Spain, ${ }^{2} \mathrm{HU} 12$ de Octubre, Madrid, Spain; ${ }^{3} \mathrm{HU}$ Gregorio Marañón, Madrid, Spain; ${ }^{4} \mathrm{HU}$ Niño Jesús, Madrid, Spain; ${ }^{5} \mathrm{HU}$ Fundación Alcorcón, Madrid, Spain; ${ }^{6}$ Instituto Salud Musculoesquelética Inmusc, Madrid, Spain; ${ }^{7} \mathrm{HU}$ La Paz, Madrid, Spain

Background: Juvenile idiopathic inflammatory myopathies (JIIM) are a heterogeneous group of autoimmune diseases affecting children, characterized by symmetric muscular weakness, cutaneous rash and systemic organ involvement. Given its low incidence, there are few studies describing the characteristics of this disease and its subtypes in Spanish patients ${ }^{1}$.

Objectives: To describe the demographic, clinical and analytical characteristics of patients with JIIM from the registry of inflammatory myopathies in Madrid community (REMICAM), and to compare those measures between polymyositis (PM) and juvenile dermatomyositis (JDM) subgroups. Methods: A multicentre retrospective study from the REMICAM registry was performed. Patients were selected if they were 18 years or younger at onset of JIIM and met definite or probable criteria for IIM by the modified Bohan and Peter criteria. We included patients with JDM or PM subgroups, overlap myositis patients were excluded.

Results: 86 patients were included, 12 classified as PM and 74 as JDM. $70 \%$ were women and $96 \%$ were Caucasian. Mean age at diagnosis was 11.8 years in PM group vs 7.2 years in JDM group. 44\% presented arthritis and $93 \%$ presented muscular weakness. Gottron sign was present in $76 \%$ of the patients, and calcinosis was present in $31.4 \%$. Cardiac and pulmonary manifestations were rare $(<5 \%)$. There were no cases of neoplastic disease. Clinical features and complementary analysis are shown in table 1 and table 2.

Abstract THU0522 -Table 1. Clinical features

\begin{tabular}{lcccc}
\hline & $\begin{array}{c}\text { Total } \\
(\mathbf{n}=86)\end{array}$ & $\begin{array}{c}\text { PM } \\
(\mathbf{n}=12)\end{array}$ & $\begin{array}{c}\text { JDM } \\
(\mathbf{n}=74)\end{array}$ & p-value \\
\hline Fever & $23(29,1 \%)$ & $6(50,0 \%)$ & $17(25,4 \%)$ & 0,084 \\
Weight loss & $12(15,2 \%)$ & $1(8,3 \%)$ & $11(16,4 \%)$ & 0,680 \\
Arthralgia & $38(44,2 \%)$ & $7(58,3 \%)$ & $31(41,9 \%)$ & 0,287 \\
Arthritis & $24(28,4 \%)$ & $6(50 \%)$ & $18(24,7 \%)$ & 0,071 \\
Gottron sign & $66(76,7 \%)$ & & $65(87,8 \%)$ & \\
Heliotrope erythema & $46(53,5 \%)$ & & $46(62,2 \%)$ & \\
Mechanic hands & $10(12,3 \%)$ & & $10(14,5 \%)$ & \\
Skin ulcers & $3(3,7 \%)$ & & $3(4,3 \%)$ & \\
Raynaud & $12(13,9 \%)$ & $3(25,0 \%)$ & $9(12,2 \%)$ & 0,362 \\
Calcinosis & $27(31,4 \%)$ & $2(16,7 \%$ & $25(33,8 \%)$ & 0,325 \\
Muscular weakness & $80(93,0 \%)$ & $11(91,7 \%)$ & $69(93,2 \%)$ & 1,000 \\
Myalgia & $68(83,9 \%)$ & $8(66,7 \%)$ & $60(87,0 \%)$ & 0,095 \\
Myocarditis & $2(2,3 \%)$ & & $2(2,7 \%)$ & \\
Arrythmia & $3(3,5 \%)$ & $1(8,3 \%)$ & $2(2,7 \%)$ & 0,370 \\
Heart failure & $1(1,2 \%)$ & & $1(1,4 \%)$ & 1,000 \\
Interstitial lung disease & $1(1,2 \%)$ & $1(8,3 \%)$ & & 0,140 \\
Dysphagia & $19(22,1 \%)$ & $2(16,7 \%)$ & $17(23,0 \%)$ & 1,000 \\
GI reflux & $7(8,1 \%)$ & $1(8,3 \%)$ & $6(8,1 \%)$ & 1,000 \\
Gl hemorrhage & $1(1,2 \%)$ & & $1(1,3 \%)$ & 1,000 \\
\hline
\end{tabular}

Abstract THU052 -Table 2. Complementary test.

\begin{tabular}{lcccc}
\hline & $\begin{array}{c}\text { Total } \\
(\mathbf{n}=\mathbf{8 6})\end{array}$ & $\begin{array}{c}\text { PM } \\
(\mathbf{n = 1 2})\end{array}$ & $\begin{array}{c}\text { JDM } \\
(\mathbf{n}=\mathbf{7 4})\end{array}$ & $\begin{array}{c}\mathbf{p}- \\
\text { value }\end{array}$ \\
\hline Anemia & $13(15,1 \%)$ & $4(33,3 \%)$ & $9(12,2 \%)$ & 0,079 \\
Leukopenia & $4(4,6 \%)$ & $1(8,3 \%)$ & $3(4,0 \%)$ & 0,458 \\
Thrombocytopenia & $3(3,5 \%)$ & $2(16,7 \%)$ & $1(1,3 \%)$ & 0,050 \\
ANA+ & $34(40,5 \%)$ & $7(58,3 \%)$ & $27(37,5 \%)$ & 0,173 \\
Anti-Jo1 & $2(2,6 \%)$ & & $2(3,0 \%)$ & 1,000 \\
CPK & $431(97-$ & $206(36-$ & $659(104-$ & 0,730 \\
& $3131)$ & $7428)$ & $3110)$ & \\
Aldolase & $12(9-18)$ & $9(5-12)$ & $12(9-19)$ & 0,230 \\
CRP & $0,35(0-1,3)$ & $0,12(0-2,8)$ & $0,42(0-1,3)$ & 0,817 \\
ESR & $19(11-29)$ & $25(13-42)$ & $19(11-29)$ & 0,450 \\
Myopathic pattern & $72(92,3 \%)$ & $12(100 \%)$ & $60(90,1 \%)$ & 0,508 \\
\hline
\end{tabular}

Conclusion: JDM was the most frequent form of MIIJ in our study $(86 \%)$. The most frequent manifestations were the muscular and dermatological ones, but an important group also presented arthritis and fever. There was no statistical difference between both groups, regardless, myalgias and dysphagia were more common in JDM group, and they had higher CPK and aldolase values. PM patients were older, had more fever and arthritis, also, cytopenia and ANA positivity were more common.

\section{REFERENCE:}

[1] Shah M, Mamyrova G, Targoff IN, Huber AM, Malley JD, Rice MM, et al. The Clinical Phenotypes of the Juvenile Idiopathic Inflammatory Myopathies. Medicine (Baltimore). 2013 Jan;92(1):25-41.

Disclosure of Interests: Jesús Loarce-Martos: None declared, Carmen Larena: None declared, M. Ángeles Blázquez: None declared, Beatriz JovenIbáñez Speakers bureau: Celgene, Novartis, MSD, Pfizer, AbbVie, and Janssen, Patricia Carreira: None declared, Francisco J López-Longo: None declared, Julia Martinez-Barrio: None declared, J.C. López Robledillo: None declared, RAQUEL ALMODOVAR: None declared, María Jesús García de Yébenes: None declared, Laura Nuño: None declared DOI: 10.1136/annrheumdis-2019-eular.4947

\section{THU0523 OBESITY IS ASSOCIATED WITH SEVERE RENAL INVOLVEMENT, PERSISTENT PURPURA AND LONGER JOINT SYMPTOMS IN CHILDREN WITH HENOCH SHÖNLEIN PURPURA}

$\underline{\text { Hatice Adiguzel Dundar }}^{1,1}$, Mehmet Pektanc $^{2}$, Meral Torun Bayram ${ }^{3}$, Alper Soylu $^{4}$, Salih Kavukcu $4^{4}{ }^{1}$ Dokuz Eylul University Faculty of Medicine, Department of Pediatrics, Pediatric Rheumatology Unit, izmir, Turkey; ${ }^{2}$ Dokuz Eylul University Faculty of Medicine, Department of Pediatrics, izmir, Turkey; ${ }^{3}$ Dokuz Eylul University Faculty of Medicine, Department of Pediatrics, Pediatric Nephrology Unit, izmir, Turkey; ${ }^{4}$ Dokuz Eylul University Faculty of Medicine, Department of Pediatrics, Pediatric Nephrology and Rheumatology Unit, izmir, Turkey

Background: Over the last 20 years, the prevalence of obesity is increased in the developed and developing countries. Adipose tissue has an effect on inflammatory processes and immune system besides metabolic and appetite regulating mechanisms. On this basis, it is now of major interest to clarify the relationship between obesity and autoimmune/ inflammatory diseases $(1,2)$.

Objectives: We aimed to evaluate the role of obesity on the clinical course and response to treatment in patients with Henoch Shönlein Purpura (HSP).

Methods: Data charts of children with HSP followed in Dokuz Eylül University Childrens' Hospital were reviewed retrospectively. Obesity was defined as BMI $\geq 95$ percentile in conformity with Centers for Disease Control and Prevention (CDC) (3). Persistant purpura was defined as skin involvement persisting for $\geq 30$ days. Mild nephropathy was defined by the presence of microscopical hematuria and/or nonnephrotic proteinuria, and severe nephropathy by nephrotic syndrome and/or acute nephritic syndrome and/or renal insufficiency (4). Patients were grouped as obese and non-obese depending on BMI. Two groups were compared for demographic, clinical and laboratory parameters.

Results: There were 199 patients [M/F:104/95; presenting age 7.1 years (range 5.0-9.2); follow-up period 17.5 months (range 3-50)]. Obesity was 